\title{
Antiplatelet activity of white and pink Nelumbo nucifera Gaertn flowers
}

\author{
Brindha Durairaj*, Arthi Dorai \\ Department of Biochemistry, PSG College of Arts and Science, Tamil Nadu, India
}

\begin{abstract}
Nelumbo nucifera Gaertn (Nelumbonaceae) a plant used in Ayurvedic medicine (common name: lotus), is a perennial, large and rhizomatous aquatic herb most prevalent in South India. Preliminary phytochemical screening of both white and pink Nelumbo nucifera flowers revealed the presence of phytochemical constituents (flavonoids, alkaloids, phenols etc,). Hence, an attempt has been made to screen the effect of Nelumbo nucifera flowers (both types) on platelet aggregation. The antiplatelet activity of hydroethanolic

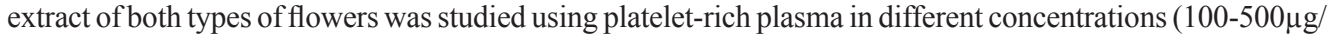
$\mathrm{ml})$. Both white and pink Nelumbo nucifera flower extracts showed dose-dependent effective antiplatelet activity with maximum activity at $500 \mu \mathrm{g} / \mathrm{ml}$ concentration; prevention of platelet aggregation was $50 \%$ of that achieved with standard aspirin. Furthermore, the antiplatelet activity of white flowers was relatively high ( $<<0.05$; ANOVA) compared to pink flowers. In conclusion, these observations suggest that both varieties of Nelumbo nucifera flower extracts exert different levels of inhibitory action on platelets in vitro (secretion and platelet aggregation suppression) due to differences in phytochemical content (alkaloids, flavonoids, phenols, tannins, phytosteroids, glycosides and saponins).
\end{abstract}

Uniterms: Nelumbo nucifera Gaertn./phytochemical constituents. Nelumbo nucifera Gaertn./pharmacognosy. Nelumbo nucifera Gaertn./Antiplatelet activity. Ayurvedic medicine. Natural products. Aspirin.

Nelumbo nucifera Gaertn (Nelumbonaceae, planta utilizada na medicina Ayurvédica, é erva aquática rizomatosa grande, predominante no sul da Índia. A triagem fitoquímica preliminar das flores brancas e cor-de-rosa de Nelumbo nucifera revelou a presença de constituintes fitoquímicos (flavonoides, alcaloides, fenóis etc). Assim, tentou-se a triagem do efeito das flores de Nelumbo nucifera de ambos os tipos na agregação plaquetária. A atividade antiplaquetária dos extratos hidroetanólico de ambos os tipos de flores foi estudada, utilizando-se plasma rico em plaquetas em duas diferentes concentrações $(100-500 \mu \mathrm{g} / \mathrm{mL})$. Tanto os extratos das flores brancas quanto daquelas de cor-de-rosa mostraram atividade antiplaquetária dose-dependente, com o máximo na concentração de $500 \mu \mathrm{g} / \mathrm{mL}$. A prevenção da agregação plaquetária foi $50 \%$ daquela alcançada com o padrão de ácido acetilsalicílico. Além disso, a atividade antiplaquetária das flores brancas foi, relativamente, alta ( $\mathrm{p}<0,05$; ANOVA), comparativamente às flores cor-de-rosa. Estas observações sugerem que ambas as variedades de extratos de flores de Nelumbo nucifera exercem diferentes níveis de ação inibitória nas plaquetas in vitro (supressão da secreção e da agregação plaquetária) devido a diferentes constituintes fitoquímicos (alcaloides, flavonoides, fenóis, taninos, fitoesteróides, glicosídeos e saponinas).

Unitermos: Nelumbo nucifera Gaertn./constituintes fitoquímicos. Nelumbo nucifera Gaertn./farmacognosia. Nelumbo nucifera Gaertn./atividade antiplaquetária. Medicina Ayurvédica. Produtos naturais. Ácido acetilsalicílico.

\section{INTRODUCTION}

Platelets play a prominent role in homeostasis and thrombosis. The normal haemostatic system limits blood

*Correspondence: Dr. D. Brindha. Department of Biochemistry, PSG College of Arts and Science, Coimbatore-641 014, Tamil Nadu, India. E-mail: brindhavenkatesh@ymail.com loss by regulated interactions between components of vessel wall, circulating blood platelets and plasma proteins (Saengkhae et al., 2008). Platelets can adhere to the walls of the blood vessels, release bioreactive compounds and aggregate to each other. These properties increase to a well established level in conditions of arterial thrombosis and atherogenesis (Guyton, 1991). 
Several antiplatelet drugs have been developed to inhibit platelet activity in acute thrombotic situations as well as to prevent adverse events. Antiplatelet therapy is one of the most effective therapies for treatment of atherothrombotic disease. Considering the recently proved role of platelets in atherosclerosis the long-term use of antiplatelet drugs could also be postulated to slow down progression of the disease (Olas et al., 2005). Therefore, the compounds that inhibit platelet function are of great interest, and it has also been shown that some plants, such as garlic and tomato may be beneficial in protecting against cardiovascular diseases as a result of platelet aggregation inhibition. Medicinal plants are rich in bioactive compounds (flavonoids, polyphenolic, vitamins and carotenoids) which inhibit platelet function (Olas et al., 2005).

Nelumbo nucifera Gaertn (Nelumbonaceae), commonly known as Indian lotus, have been widely used in folk medicine for the treatment of various inflammatory and infectious diseases (Liu et al., 2004). Studies using in vitro and in vivo models have demonstrated that this plant has antidiabetic, antipyretic, anti-inflammatory, anticancerous, antimicrobial, antiviral and anti-obesity properties (Kashiwada et al., 2005). Furthermore, Nelumbo nucifera flowers are served as healthy beverages to treat hypertension, cancer, diarrhea, fever, weakness, infection and body heat imbalance (Saengkhae et al., 2008).

The major constituents isolated from the lotus plant are alkaloids (liensinine, neferine, nuciferine, remrefidine and isoliensinine) and flavonoids $((+)-1(\mathrm{R})$-coclaurine, $(-)-1(\mathrm{~S})$-norcoclaurine and quercetin 3-O-b-D-glucuronide) (Sridhar and Rajeev, 2007). One of the most potent mechanisms by which flavonoids inhibit platelet aggregation is by mediating increase in platelet cyclic AMP levels by either stimulation of adenylate cyclase or inhibition of cAMP phosphodiesterase activity (Iman et al., 2009). The composition of flavonoids, polyphenols, alkaloids and natural antioxidants present in pink and white flowers is completely different (Iman et al., 2009). Therefore the present study was designed to evaluate the antiplatelet activity of hydroethanolic extract of white and pink Nelumbo nucifera flowers (phytochemical composition is different in both varieties) and to elucidate the inhibitory mechanisms of flavonoids in platelet aggregation. Furthermore, it is a well-known fact that many patients taking aspirin continue to have adverse cardiovascular events. One potential explanation for aspirin failure is variable response of individual patients to aspirin with consequent inadequate platelet inhibition. Previous studies have estimated that adequate anti-platelet effect is not achieved in $0.4-35 \%$ patients taking aspirin, leading to increased occurrence of cardiovascular diseases (Eikelboom et al., 2002). Hence, there is a need to seek medicinal plants and their natural constituents which show minimal side effects. It is in this context the present study is carried out.

\section{MATERIALS AND METHODS}

\section{Plant material}

The flowers of Nelumbo nucifera were collected from different localities of Coimbatore District, Tamil Nadu in September 2008 and authenticated by the Botanical Survey of India (BSI) in "Tamil Nadu Agriculture University" Coimbatore, Tamil Nadu, India. A voucher specimen (No.BSI/SC/5/23/09-10/Tech.279 MH) has been deposited at the Herbarium of the Botany department of "Tamil Nadu Agriculture University" for future reference.

\section{Plant extraction}

The air-dried and powdered flowers (100g each) were cold macerated with $50 \%$ ethanol for 3 days, with occasional stirring. After 3 days, the suspension was filtered through a fine muslin cloth and was evaporated to dryness at low temperature $\left(<40^{\circ} \mathrm{C}\right)$ under reduced pressure in a rotary evaporator. Dark brown colored crystals of approximately $8 \mathrm{~g}$ were stored in an air-tight dessicator and used for further analysis.

\section{Phytochemical screening}

Qualitative phytochemical screening of both white and pink Nelumbo nucifera flowers of different solvent extracts was carried out (Khandelwal, 2002) to test for the presence of secondary metabolites including alkaloids, flavonoids, phenols, tannins, steroids, glycosides and saponins.

\section{Antiplatelet activity}

Platelet-rich plasma and Tyrode buffer were used for the antiplatelet activity according to Iman et al. (2009). Platelet-rich plasma (PRP) was prepared by centrifugation of citrated blood at $22^{\circ} \mathrm{C}$ for $6 \mathrm{~min}$, at $400 \mathrm{~g}$. Platelets were adjusted to $3.0 \times 10^{8}$ cell $/ \mathrm{ml}$ with sterile saline. Tyrode buffer was prepared using sodium chloride $149 \mathrm{mM}$, potassium chloride $2.6 \mathrm{mM}$, sodium bicarbonate $9.5 \mathrm{mM}$, glucose $5.5 \mathrm{mM}$, sodium dihydrogen phosphate $0.5 \mathrm{mM}$, magnesium chloride $0.6 \mathrm{mM}$ and gelatin $0.25 \%$. The platelet-rich plasma $0.13 \times 10^{-7}$ for each assay was resuspended in Tyrode buffer ( $\mathrm{pH}$ adjusted to 7.4 with $0.25 \mathrm{M} \mathrm{Hcl}$ ). Aggregation of the platelets was induced by 
$\mathrm{CaCl}_{2}$ at a final concentration of $2 \mu \mathrm{M}$. Platelet aggregation was recorded by increasing transmittance value of spectrophotometric measurements. To determine the in vitro antiplatelet aggregation property, different concentrations $(100,200,300,400$ and $500 \mu \mathrm{g} / \mathrm{ml})$ of plant extract were added to the platelet suspension for $1 \mathrm{~min}$ exposure at $37^{\circ} \mathrm{C}$ before treatment with platelet aggregating agents. Aspirin at $500 \mu \mathrm{g} / \mathrm{ml}$ was used as a standard.

\section{RESULTS AND DISCUSSION}

Platelet dysfunction contributes to the development and progression of many cardiovascular diseases such as arterial hypertension, atherosclerosis and thrombosis. Indeed, it has been reported that patients with hypertension or coronary heart disease tend to have increased platelet reactivity. Therefore, many investigations were carried out toward the prevention of the abnormal hyperactivity of platelets reported in cardiovascular disorders employing different therapies, including use of medicinal plants (Massberg et al., 2005). The objective of the present study was to determine whether both white and pink Nelumbo nucifera flower extracts would affect platelet function and blood coagulation.

The preliminary phytochemical screening is shown in Tables I and II. From the results it was evident that all the solvent extracts were found to contain selected analysed phytochemicals. When compared with different solvent extracts, hydroethanolic extract was found to contain major active phytoconstituents such as alkaloids, flavonoids, phenols, tannins, steroids, glycosides and saponins screened in both white and pink flowers of the plant. In white flowers, relatively higher amounts of phytochemicals were present (Tables 1 and II). In hydroethanolic extract (used in the present study) the phytochemicals are present in relatively higher amounts in white flowers. (Tables I and II). These results are in accordance with Babayi et al. (2004) who reported that the phytochemical analysis of the crude extracts of Eucalyptus revealed the presence of saponin, glycosides, steroid, tannins and phenols.

From Figures 1 and 2 it is evident that both white and pink Nelumbo nucifera flower extracts showed effective antiplatelet activity in a dose-dependent manner with maximum activity at $500 \mu \mathrm{g} / \mathrm{ml}$ concentration. Furthermore, the antiplatelet activity of white flowers was relatively high $(\mathrm{p}<0.05$; ANOVA) compared to the pink flowers. However, prevention of platelet aggregation was lower compared to standard aspirin at $500 \mu \mathrm{g} / \mathrm{ml}$ concentration. The flavonoids present in hydroethanolic extract might have prevented the adhesion and aggregation of platelets besides release of cytoplasmic calcium that stimulates the release of ADP. These results are in accordance with those of other studies demonstrating that flavonoid compounds isolated from many plants, including the Solidago species, inhibit platelet aggregation (Koleckar et al., 2008).

There are numerous pathways leading to platelet aggregation. Prostaglandins (PG) and serotonin (5-HT) are considered the major chemical mediators of platelet aggregation (Ogawa et al., 1998). The clinical study of platelet aggregation reveals that both lotus flower extracts

TABLE I - Phytochemical screening of white Nelumbo nucifera flowers in different solvent extracts

\begin{tabular}{llccccccc}
\hline S.No & Extract & Alkaloids & Flavonoids & Phenols & Tannins & Steroids & Glycosides & Saponins \\
\hline 1. & $50 \%$ Ethanol & ++ & ++ & ++ & + & + & ++ & - \\
2. & Benzene & + & ++ & + & + & - & + & - \\
3. & Chloroform & + & - & + & ++ & + & ++ & + \\
4. & Petroleum ether & ++ & + & - & + & + & - & + \\
5. & Water & + & + & - & - & + & - & + \\
\hline
\end{tabular}

TABLE II - Phytochemical screening of pink Nelumbo nucifera flowers in different solvent extracts

\begin{tabular}{llccccccc}
\hline S.No & Extract & Alkaloids & Flavonoids & Phenols & Tannins & Steroids & Glycosides & Saponins \\
\hline 1. & $50 \%$ Ethanol & + & + & + & + & + & + & - \\
2. & Benzene & + & - & + & + & - & + & - \\
3. & Chloroform & - & + & - & - & + & + & + \\
4. & Petroleum ether & - & + & - & - & + & - & - \\
5. & Water & + & + & - & - & - & - & - \\
\hline
\end{tabular}

+ Presence; - Absence 
Antiplatelet activity of white Nelumbo nucifera flower

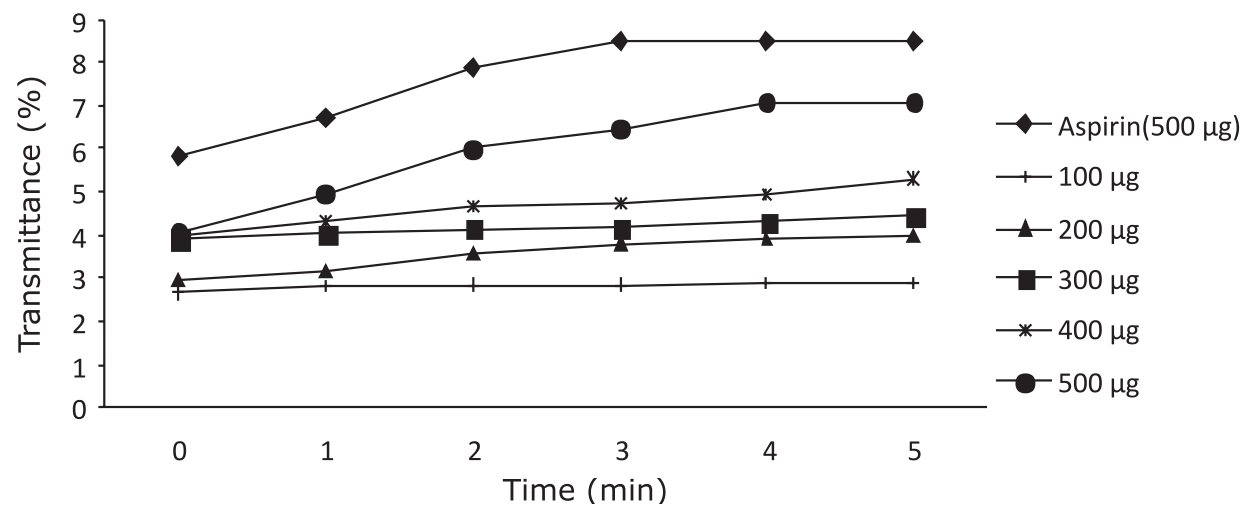

FIGURE 1 - Antiplatelet activity of hydroethanolic extract of white Nelumbo nucifera flower extract

$(\diamond)$ antiplatelet activity of Aspirin at $500 \mu \mathrm{g} / \mathrm{mL} ;(+)$ antiplatelet activity of hydroethanolic extract of white flower extract at $100 \mu \mathrm{g} / \mathrm{mL} ;(\boldsymbol{\Delta})$ antiplatelet activity of hydroethanolic extract of white flower extract at $200 \mu \mathrm{g} / \mathrm{mL}$; (-) antiplatelet activity of hydroethanolic extract of white flower extract at $300 \mu \mathrm{g} / \mathrm{mL} ;(*)$ antiplatelet activity of hydroethanolic extract of white flower extract at $400 \mu \mathrm{g} / \mathrm{mL} ;(\bullet)$ antiplatelet activity of hydroethanolic extract of white flower extract at $500 \mu \mathrm{g} / \mathrm{mL}$.

Antiplatelet activity of Pink Nelumbo nucifera flower

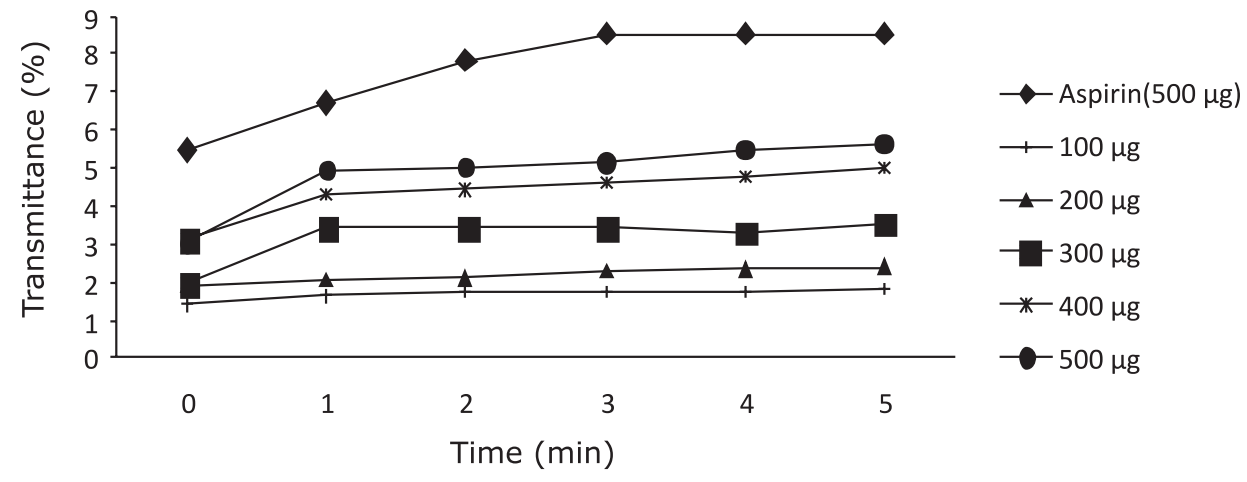

FIGURE 2 - Antiplatelet activity of hydroethanolic extract of pink Nelumbo nucifera flower extract

(४) antiplatelet activity of Aspirin at $500 \mu \mathrm{g} / \mathrm{mL} ;(+)$ antiplatelet activity of hydroethanolic extract of pink flower extract at $100 \mu \mathrm{g} / \mathrm{mL} ;(\boldsymbol{\Delta})$ antiplatelet activity of hydroethanolic extract of pink flower extract at $200 \mu \mathrm{g} / \mathrm{mL}$; (-) antiplatelet activity of hydroethanolic extract of pink flower extract at $300 \mu \mathrm{g} / \mathrm{mL} ;(*)$ antiplatelet activity of hydroethanolic extract of pink flower extract at $400 \mu \mathrm{g} / \mathrm{mL} ;(\bullet)$ antiplatelet activity of hydroethanolic extract of pink flower extract at $500 \mu \mathrm{g} / \mathrm{mL}$.

can either inhibit the PG synthesis pathway of 5-HT release. In addition, other studies have also demonstrated that saponins are effective in inhibiting platelet aggregation induced by ADP, by blocking the receptor-dependent $\mathrm{Ca}^{2+}$ influx of human platelets and/or inhibiting the production of leukotriene (Zeng et al., 2004).

\section{CONCLUSION}

The obtained data indicated that the hydroethanolic extracts of both white and pink Nelumbo nucifera flowers possess potent antiplatelet activity limited to primary haemostasis in human blood. In addition, the antiplatelet activity of white flowers is relatively high compared to the pink flowers due to different composition of phytochemicals. However, further studies are needed to confirm the mode of action and efficacy of both Nelumbo nucifera flower extracts in platelet aggregation.

\section{REFERENCES}

BABAYI, H.; KOLO, J.I.; OKOGUN, U.; IJAH, J. The Phytochemical screening and antimicrobial activities of methanolic extracts of Eucalyptus camaldulensis and Terminalia catappa against some pathogenic microorganisms. Biokemistri, v.16, p.106-111, 2004. 
EIKELBOOM, J.W.; HIRSH, J.; WEITZ, J.I.; JOHNSTON, M.; YI, Q.; YUSUF, S. Aspirin-resistant thromboxane biosynthesis and the risk of myocardial infarction, stroke, or cardiovascular death in patients at high risk for cardiovascular events. Circulation, v.105, p.1650-1655, 2002.

GUYTON, A.C.; HALL J.E. Textbook of medical physiology. 10.ed. Singapore: Harcourt Asia Pvt. Limited, 2000. p.184222.

IMAN, R.A.; PRIYA, B.L.; CHITHRA, R.; SHALINI, K.; VASANTHI, J. Invitro antiplatelet activity guided fractionation of aerial parts of Melothria maderaspatana. Indian J. Pharm. Science, v.68, p.668-670, 2006.

KASHIWADA, Y.; ASOSHIMA, A.; IKESHIRO, Y. Anti-HIV benzylisoquinoline alkaloids from leaves of Nelumbo nucifera, and structure activity correlations with related alkaloids. Bioorg. Med. Chem., v.13, p.443-448, 2005.

KHANDELWAL, K.R. Practical pharmacognosy techniques and experiment. New Delhi: Himalaya Publishing House, 2006. v.16, p.15-163.

KOLECKAR, V.; BROJEROVA, E.; REHAKOVA, Z.; KUCA, $\mathrm{K}$. In vitro antiplatelet activity of flavonoids from Leuzea carthamoides. Drug Chem. Toxicol., v.31, p.27-35, 2008.

LIU, C.P.; TSAI, W.J.; LIN, Y.L., CHEN, C.F.; KUO, Y.C. The extracts from Nelumbo nucifera suppress cell cycle progression, cytokine genes expression, and cell proliferation in human peripheral blood mononuclear cells. Life Sci., v.75, p.699-716, 2004.
MASSBERG, S.; SCHURZINGER, K.; LORENZ, M.; KONRAD, I.; SCHULZ, C.; PLESNILA, N. Platelet adhesion via glycoprotein II integrin is critical for atheroprogression and focal cerebral ischemia: an in vivo study in mice lacking glycoprotein IIb. Circulation, v.8, p.1180-1188, 2005.

OGAWA, N.; WEISS, H.; FARMER, G. Antiplatelet drugs: pharmacological aspects. In platelets: pathophysiology and antiplatelet drugs therapy. Ann. Rev. Pharmacol. Toxicol., v.35, p.511-516, 1998.

OLAS, B.; WACHOWICZ, B.; STOCHMAL, A.; OLESZEK, W. Inhibition of blood platelet adhesion and secretion by different phenolics from Yucca schidigera Roezl. bark. Nutrition, v.45, p.199-206, 2005.

SAENGKHAE, C.; ARUNNOPPARAT, W.; SUNGKHAJORN, P. Antioxidant activity of Nelumbo nucifera Gaertn on oxidative stress-induced Erythrocyte hemolysis in hypertensive and normotensive rats. J. Physiol. Sci., v.20, p.70-78, 2008.

SRIDHAR, K.R.; RAJEEV, B. Lotus-A potential nutraceutical source. J. Agric. Technol., v.3, p.143-155, 2007.

ZENG, F.R.; YIN, S.M.; XIE, S.F.; Feng, J.H. Effects of 2A-11 on the aggregation and $\mathrm{Ca}^{2+}$ influx of platelets. J. Agric. Food Chem., v.55, p.217-221, 2004.

Received for publication on $08^{\text {th }}$ October 2009 Accepted for publication on $11^{\text {th }}$ February 2010 